\title{
HARVEST AND POPULATION CHANGE OF ROCK PTARMIGAN IN ICELAND
}

\author{
Ólafur K. NieLSEN \\ Icelandic Institute of Natural History, Urriðaholtsstrati 6-8, P.O. Box 125, \\ 212 Garðabar, Iceland. E-mail: okn@ni.is
}

\begin{abstract}
The Rock Ptarmigan (Lagopus muta) is the only upland game bird in Iceland. Presently the annual number harvested is below 100,000 birds, but was much higher earlier (max. c. 270,000 birds). The population is monitored, and this program involves: (1) an annual spring census for territorial cocks; (2) estimation of age ratios in spring; (3) estimation of age ratios in late summer; and (4) estimation of age ratios during the open season. Also, all hunters have to buy a hunting card issued by the state, and have to turn in a report on the number of birds harvested and the number of hunting days. The monitoring data show cyclic changes in ptarmigan numbers, with peaks approximately every 11 years. Further, the peaks since 1960 are lower than the peaks that characterized the early part of the $20^{\text {th }}$ century. Time-series analysis shows that since 1981 this decline amounts to c. $4 \%$ per annum. Also, these data can be used to derive two mortality rates. The first, termed $Z_{2}$, is a mortality rate shared by the two age groups (adult birds and juvenile birds). The second, termed $Z_{x, w}$, is juvenile mortality in excess of adult mortality. Hunting mortality is a part of the $Z_{2}$-term. The $Z_{x, w}$-term, or juvenile excess mortality, is what drives the cycle in a demographic sense. Analysis of the data series shows that a steady increase in the $Z_{2}$-term is the demographic reason for the decline of the population. Predictions made at the turn of the century, and based on a population model for the Rock Ptarmigan in Iceland, indicate a collapse of the ptarmigan cycle if the high values of the $Z_{2}$-term witnessed then were to continue. As a consequence of this, the Minister for the Environment closed the ptarmigan season in 2003 and 2004, a highly controversial decision at the time. The results were drastic and tell an interesting story both with respect to ptarmigan biology and human behavior.
\end{abstract}

NiELSEN, Ó. K. 2011. Harvest and population change of Rock Ptarmigan in Iceland. Abstract, page 71 in R. T. Watson, T. J. Cade, M. Fuller, G. Hunt, and E. Potapov (Eds.). Gyrfalcons and Ptarmigan in a Changing World, Volume II. The Peregrine Fund, Boise, Idaho, USA. http://dx.doi.org/10.4080/gpcw.2011.0212 
- NielSEN - 